UDC 341.1/8

DOI https://doi.org/10.32782/2524-0374/2021-12/109

\title{
RIGHT TO INFORMATION AS A MEANS TO EXECUTE THE FREEDOM OF EXPRESSION: ECHR CASES
}

\author{
ПРАВО НА ІНФОРМАЦІЮ ЯК ЗАСІБ ЗДІЙСНЕННЯ СВОБОДИ \\ НА САМОВИРАЖЕННЯ: СПРАВИ ЕСПЛ
}

\author{
Tytarenko M.O., 4th year student \\ at the Faculty of International Law \\ Yaroslav Mudriy National Law University
}

The freedom of expression, included into multiple international and national legal acts, set forth the right to receive and impart information, as established by the European Convention on Human Rights (the Convention). This link, however, does not embark positive obligation on the state to provide information to persons, not does it initially grant the right to access the information to the person. However, given the proximate cause between them, the breach of the right to information might cause the breach of the Article 10 of the Convention. The case of Yuriy Chumak v. Ukraine proves this interconnection during the journalistic activity. When a state creates obstacles for the journalist to access the information necessary for their journalistic research that stands public interest, it falls under the category of a breach of the Article 10 of the Convention. However, is it possible to seek remedy for the person who is not involved in any journalistic activity?

The decision of the European Court of Human Rights (the Court) on the case of Magyar Helsinki Bizottság v. Hungary included the member of the NGO into the category of people protected by the Article 10, applying the term "watchdog" to the applicant. This term is an "umbrella term" that implies the oversight functions of both governmental and non-governmental organizations, as well as individuals and media. Therefore, the applicant fit into the category of a "watchdog".

This proves that the development of technologies and society is broadening the established perception of "watchdogs" as well as the development of the connection between the right to information and freedom of expression on contemporary society. Therefore, protection of such right and freedom, states' obligation to ensure them is necessary for the further development of a democratic society.

Key words: Human rights Law, breach of freedom of expression, access to public information, journalistic activity, watchdog.

Свобода самовираження, включена до багатьох міжнародних і національних правових актів, закріплює право на отримання та поширення інформації, як це встановлено Європейською конвенцією з прав людини. Однак це положення безпосередньо не покладає на державу позитивного зобов'язання надавати інформацію особам і не надає особі права на доступ до такої інформації. Однак, з огляду на безпосередній зв'язок між ними, порушення права на інформацію може призвести до порушення статті 10 Конвенції. Справа «Юрій Чумак проти України» підтверджує цей взаємозв'язок під час журналістської діяльності позивача. Коли держава створює перешкоди для журналіста в доступі до інформації, необхідної для його журналістського дослідження, що становить суспільний інтерес, це безпосередньо підпадає під порушення статті 10 Конвенції. Але чи можна шукати засіб захисту для особи, яка не займається журналістською діяльністю, однак яка потребує доступу до інформації з певних причин?

Рішення Європейського суду з прав людини у справі "Magyar Helsinki Bizottság v. Hungary" включило члена недержавної організації до категорії осіб, що підпадають під дію статті 10 Конвенції, застосовуючи до заявника термін «спостерігач» ("watchdog"). Цей термін $€$ загальним терміном, який означає наглядові функції як урядових, так і неурядових організацій, а також окремих осіб і ЗмІ. Таким чином, заявник у цій справі вписується в категорію «спостерігач».

Це свідчить про те, що розвиток технологій і суспільства розширює усталене уявлення про «спостерігачів», а також розвиває зв'язок між правом на інформацію та свободою самовираження в сучасному суспільстві. Тому для подальшого розвитку демократичного суспільства необхідне закріплення й захист цих прав і свобод, установлення зобов'язань держав щодо їх забезпечення.

Ключові слова: міжнародне право прав людини, порушення свободи самовираження, доступ до публічної інформації, журналістська діяльність, спостерігач

Freedom of expression was, is and will be a relevant topic for discussion in the legal society and the whole world. Despite there being an incredible development in its enforcement, there are still some countries that limit and prohibit certain forms of expression to the extent of criminalizing them. Amnesty International underlines the fact that within the period of 2018 Egypt has arrested at least 113 persons for expressing their opinions and beliefs, for the reasons of criticizing the government as well as for "satire, tweeting, supporting football clubs, denouncing sexual harassment, editing movies and giving interviews" [1].

Analysis of international law and national legislations has shown that freedom of expression has earned a solid and essential place among people's rights and freedoms in many countries and systems. The International Covenant on Civil and Political Rights in Art. 19 [2], the Universal Declaration of Human Rights in Art. 19 [3], European Convention on Human Rights in Art. 10 [4], Convention on the Rights of the Child in Art. 13 [5]. It can also be seen in the First Amendment to the Constitution of the US, prohibiting any laws restricting the "free exercise or abridging the freedom of speech, or of the press" [6].

Amnesty International emphasizes the role of the freedom of expression and its impact on the international law: "The right to freedom of expression is enshrined in Article 19 of the Uni- versal Declaration of Human Rights, which sets out in broad terms the human rights that each of us has. It was later protected legally by a raft of international and regional treaties."

Furthermore, it is well known that The Council of Europe, being one of the most influential human rights promoting organizations, has forty-seven member states, meaning that these States took responsibility to ensure European Convention on Human Rights compliance within their jurisdictions. Therefore, the freedom of expression stated in the Article 10 of the European Convention on Human Rights is also subject to ensuring by the member states.

The issue of compatibility of the freedom of expression and right to information would not typically raise any questions given the content of the art. 10 of the European Convention of Human Rights. It sets forth: "Everyone has the right to freedom of expression. This right shall include freedom to hold opinions and to receive and impart information and ideas without interference by public authority and regardless of frontiers. This Article shall not prevent States from requiring the licensing of broadcasting, television or cinema enterprises" [4]. It would be logical to assume that in order to express oneself a person might require information, hence, the right to obtain information is interconnected with the freedom of expression. And, being fundamental in its nature, the freedom of expression constitutes State's positive obligations to ensure such 
freedom. Therefore, in order to ensure person's freedom of expression, the State might be required to provide them with information requested. Such obligation can be dismissed in case of a state secret, etc.

However, does such logic work vice versa? If a person were rejected their access to information does that violate their freedom of expression? Having the right to information breached is not enough to file a claim under the Art. 10 of the Convention. It is necessary to prove the proximate cause between the right to information and freedom of expression. Such cause might be shown as publication and research.

The following might as well be the job of a journalist as in the case of Yuriy Chumak v. Ukraine. The details of the case are following: Yuriy Chumak, working as a journalist and being a member of a non-governmental organization, the Kharkiv Human Rights Protection Group ("the NGO"); and a deputy editor of its bulletin Human Rights, submitted a written information request to the President of Ukraine in relation to the practice of unlawful restriction (by restrictive classifications which had not been prescribed by law) of access to normative legal acts. As no response had been given, the applicant filed a claim to the court to recognize the refusal to provide information and that such refusal was unlawful, as well as demanding to provide the information they needed. The applicant stated that the documents they requested were not subject to any restriction and they were necessary for their journalistic article. The first-instance court rejected their claim, arguing that, under the Information Act, persons have a right to information "as may be required for the implementation of their rights, freedoms, and lawful interests, as well as for carrying out their tasks and their functions. The information requested by Y.V. Chumak was not information concerning him personally, and therefore, was not required for the implementation of his rights and interests". The applicant appealed, stating that the court had mistakenly interpreted the provisions of the Act, and had not explained the way the information did not concern them personally. The applicant's appeal was rejected in the second-instance court on the same grounds as the first-instance court's decision. The applicant therefore filed a claim to the European Court of Human Rights under Article 10 of the Convention [7].

Having the theoretical five-step procedure while deciding upon any case in the ECHR, the initial step must be admissibility. This procedure decides whether the claim is to be decided upon in the ECHR and under which article it shall be admissible [8, p. 14]. The Article 10 of the Convention regulates the freedom of expression, therefore, the court was to find the correlation between the applicant's right to information and the freedom of expression. And, although the State did not raise any objection as regarding the application of the Article, the Court decides to address the issue of its own motion.

The Court made it clear that the Article 10 itself does not impose any obligation on the Government to provide access to the information, neither does it grant an individual the right to information held by a public authority. However, such right and obligation might occur when it serves an instrument to the person's freedom of expression.

The right to access to information concerning national legal acts has also been developed by the European Court of Justice (see, T.V. Komarova Court of Justice of the European Union: development of the judicial system and practice of interpretation of EU law: monograph) [9].

While deciding upon the case, the Court followed the principles set forth in another case, Magyar Helsinki Bizottság v. Hungary, 1) the purpose of the information request, 2) the nature of the requested information, 3) the role of the applicant, 4) and whether the information was ready and accessible [10].

It was established that the applicant needed the information for the purpose of drafting their journalistic article, the nature of the information sought (dates and names of the President's decrees) was decided to meet the public-interest test "where disclosure provides transparency on the manner of conduct of public affairs and on matters of interest for society as a whole and thereby allows participation in public governance by the general public" therefore, since those were the titles of legal acts issues by the Head of the State, the information was undoubtedly of public interest "because the public needed to know the domains in which legal rules existed and could affect them". The role of the applicant was established as the journalist and the readiness and accessibility of the information was beyond any doubt since the decrees were issued two years before the information request and were declassified by the existing law [7]

This case set forth the principle of admissibility of information access breach claims under the Article 10 of the Convention. The decision therefore stated that since the information was necessary to fulfill the applicant's journalistic obligations, such is article drafting, it breached their freedom of expression in part of information access. The State's refusal to provide such information made it impossible for the journalist to publish their writing.

As can be seen from the case, if a journalist requires some information for the purpose of fulfilling their journalistic obligations, shall the information be legally accessible, the government has to provide them an access to such information, lest there be a breach of the Article 10 of the Convention.

And such breach might not only take form of a refusal to certain information (see also, Társaság a Szabadságjogokért v. Hungary), denying a journalist their access to certain institutions and places if they require it for their journalistic purposes (see, Szurovecz v. Hungary, Selmani and Others v. the former Yugoslav Republic of Macedonia) or restricting the journalist to take photos (see, Butkevich v. Russia).

However, is it only admissible where the applicant is a journalist? Who is a journalist and can a non-journalist seek remedy for the breach of their right to information when researching or gathering materials for their personal posts in social media or any other form of expression? Or, more importantly, does that meet the public-interest test?

The answer to the questions can be found in the ECHR decision on the case of Magyar Helsinki Bizottság v. Hungary.

Magyar Helsinki Bizottság (Hungarian Helsinki Committee), being a non-governmental organization, requested information about the names of the public defenders selected in 2008 and the number of assignments given to each lawyer from a total of twenty-eight police departments, situated in the seven Hungarian regions. The aim of the data request was to demonstrate whether there existed discrepancies in police departments' practice in appointing defence counsel from the lists provided by the bar associations. Seventeen police departments complied with the request; a further five police departments disclosed the requested information following a successful legal challenge by the applicant NGO. The applicant's request has been denied due to absence of public interest and the information being of private nature. The State argued that the Article 10 was not applicable in this case, since the article 10 does not include the freedom to "seek" information but only to "receive" and "impart" it, which was not the case of the NGO. The question brought before the Court was also the level of protection provided to the NGO compared to the journalists and press. Finally, can the NGO be treated as a "watchdog"? [10]

A (government) watchdogs are a phenomenon in society that exist in miscellaneous areas defined as "...institution, person or group of people whose job is to check that [governments] are not doing anything illegal or ignoring people's rights" [11].

The Oxford Handbook on Administrative Justice uses the phrase 'watchdog agencies' "as an umbrella term to capture the oversight functions of both government and non-government agencies, ranging from the courts to industry ombudsman to media including a range of mechanisms such 
as investigation, review, and inquiry for review of administrative decision-making." They act as administrative mechanisms to "reconcile the requirements of efficiency and administration and justice to the citizen' [12].

Therefore, the Court has held it clear that "the function of acting as a watchdog, that is generating and contributing to a public debate, was not restricted to professional journalists, but encompassed NGOs, researchers and individual activists". The scope of the Article 10 of the Convention does not narrow the categories of persons protected by it to journalists [5].

What was necessary for the application to be categorized as a "watchdog" was that their actions included legitimate information gathering and research that stood public interest. Such statement was initially used in the case of Társaság a Szabadságjogokért v. Hungary. And, most importantly, that there was an obstacle created by the government for the applicant during their activities.
Summarizing the cases mentioned above, there is an unarguable link between the freedom of speech and the right to information of a person, since the latter serves as an instrument to the former. The freedom to expression, being a fundamental right, spreads to any person willing to hold opinions, receive and impart information. Such formulation also implies the right to seek information. However, the issue of receiving information from a State dictates, inter alia, certain limits such as a particular role of the person. As it can be vividly seen from the Yuriy Chumak v. Ukraine case, a journalist has full right to access information unless is it classified. However, in addition to that, a person, performing a role of a "watchdog" is also subject to the Article 10 of the Convention in their right to receive, seek and impart information when it meets the criteria of public interest.

Right to information nowadays is inseparably connected with the freedom of expression, given the number of online-platforms for discussion and popularization of social media. Therefore, its protection and imposing obligations on the State to ensure it is crucial in a democratic society.

\section{REFERENCES}

1. Amnesty International - Freedom of expresion. URL: https://www.amnesty.org/en/what-we-do/freedom-of-expression/.

2. International Covenant on Civil and Political Rights, The United Nations General Assembly, 1966.

3. Universal Declaration of Human Rights, The United Nations General Assembly, 1948.

4. European Convention on Human Rights, Council of Europe, 1950.

5. Convention on the Rights of the Child, The United Nations Committee on the Rights of the Child, 1989.

6. The White House - The Constitution of the US. URL: https://www.whitehouse.gov/about-the-white-house/our-government/theconstitution.

7. CASE OF YURIY CHUMAK v. UKRAINE № 23897/10. ECLI:CE:ECHR:2021:0318JUD002389710. URL: https://hudoc.echr.coe.int/eng\#\{\%22tabview\%22:[\%22notice\%22],\%22itemid\%22:[\%22001-208598\%22]\}.

8. Michaela Daňková - Art Speech in the Case Law of the European Court of Human Rights - Diploma thesis. Masaryk University, Faculty of Law, Department of Constitutional Law and Political Science. Brno, 2018.

9. Komarova T.V. Court of Justice of the European Union: development of the judicial system and practice of interpretation of EU law: monograph. Law, 2018. P. 303-304.

10. CASE OF MAGYAR HELSINKI BIZOTTSÁG v. HUNGARY № 18030/11. ECLI:CE:ECHR:2016:1108JUD001803011. URL: https://hudoc.echr.coe.int/eng\#\{\%22appno\%22:[\%2218030/11\%22],\%22itemid\%22:[\%22001-167828\%22]\}.

11. Oxford Dictionary. 2021. URL: https://www.oxfordlearnersdictionaries.com/definition/english/watchdog.

12. Anita Stuhmcke - Government Watchdog Agencies and Administrative Justice, The Oxford Handbook of Administrative Justice. Oxford, 2021. URL: https://www.oxfordhandbooks.com/view/10.1093/oxfordhb/9780190903084.001.0001/oxfordhb-9780190903084-e-8\#notes. 